\title{
STUDI PERBANDINGAN ANALISA KETELITIAN TINGGI MENGGUNAKAN TOTAL STATION DAN SIPAT DATAR
}

\author{
Agnes Sri Mulyani', Sudarno P Tampubolon ${ }^{2 *}$ \\ ${ }^{1}$ Jurusan Teknik Sipil, Universitas Kristen Indonesia \\ Email: agnes.mulyani@uki.ac.id \\ ${ }^{2}$ Jurusan Teknik Sipil, Universitas Kristen Indonesia \\ Email: Sudarno.tampubolon@uki.ac.id
}

Masuk: 21-03-2020, revisi: 24-09-2021, diterima untuk diterbitkan: 06-10-2021

\begin{abstract}
ABSTRAK
Penelitian ini dilakukan untuk menganalisis dan mengetahui ketelitian beda tinggi menggunakan metode pengukuran beda tinggi suatu ring tertutup menggunakan Waterpass B2 dan Total Station Kolida 420SR. Lokasi penelitian terletak di daerah Ciloto, Puncak Jawa Barat dengan koordinat $107^{\circ}$ bujur timur dan $06^{\circ}$ lintang selatan, pada tanggal 14 dan 15 Desember 2014 dengan menggunakan referensi titik tinggi lokal. Pengukuran dilakukan tiga kali dengan ring yang berbeda namun titik pangkal dan ujung adalah titik yang sama. Hitungan ketelitian dilakukan dengan hitung perataan kuadrat terkecil untuk mengetahui standar deviasi hasil pengukuran dengan masing-masing alat. Hasilnya adalah standar deviasi beda tinggi dengan waterpass sebesar $0.01 \mathrm{~mm}$, sedangkan dengan Total Station sebesar $0.02 \mathrm{~mm}$. Berdasarkan hasil perhitungan nilai standar deviasi pengukuran beda tinggi, maka Total Station dapat digunakan untuk pengukuran beda tinggi pada pekerjaan teknik sipil yang tidak memerlukan ketelitian yang sangat tinggi, dan pengukuran beda tinggi dengan Total Station lebih ekonomis karena waktu yang diperlukan untuk pengukuran adalah seperempat dari waktu yang diperlukan pengukuran beda tinggi dengan Waterpass.
\end{abstract}

Kata Kunci: pengukuran beda tinggi; Waterpass; Total Station.

\begin{abstract}
This research was conducted to analyze and determine the height difference accuracy using the method of measuring the different heights of a closed loop using Waterpass B2 and Total Station Kolida 420SR. The location of research in the Ciloto area, Puncak, West Java with coordinates $107^{\circ}$ east longitude and $06^{\circ}$ south latitude, on 14-15 December 2014 using a local high point reference. Measurements were made three times with different looped but the starting and ending points were the same points. Accuracy of calculation is done by calculating the average of the least squares to determine the standard deviation of the measurement results with each equipment. The result is the standard deviation of the height difference with the waterpass is 0.01mm, while with the Total Station it is $0.02 \mathrm{~mm}$. Based on the results of the standard deviation of the height difference, the Total Station can be used for height measurements in civil engineering project that does not require very high accuracy and height difference measurements with the Total Station are more economical because the time required for measurement is a quarter of the time required height difference measurement with Waterpass.
\end{abstract}

Keywords: height measurement; Waterpass; Total station.

\section{PENDAHULUAN}

Penentuan tinggi titik-titik di permukaan bumi dapat dilakukan dengan berbagai cara, mulai dari metode yang mempunyai ketelitian yang paling rendah, yaitu barometrik, trigonometrik, takhimetrik, penentuan tinggi dengan Global Positioning System (GPS), maupun dengan metode sipat datar. Pengukuran tinggi di bidang teknik sipil sangat diperlukan untuk berbagai macam pekerjaan, misalnya pembuatan jalan raya, jalan kereta api, dermaga, pelabuhan, lapangan terbang, bendung serta pekerjaan pembangunan gedung atau pekerjaan teknik sipil lainnya. Dengan banyaknya pilihan metode dan peralatan yang tersedia, diharapkan pelaksanaan pengukuran dapat dilakukan dengan baik, sesuai dengan ketelitian yang disyaratkan serta 
pertimbangan efisiensi waktu dan tenaga serta biaya. Pelaksana pekerjaan diharapkan teliti dan seksama dalam memutuskan metode dan alat apa yang akan digunakan dalam melaksanakan pekerjaannya. Keputusan yang tepat seharusnya diambil dengan mempertimbangkan waktu dan biaya yang seefisien mungkin tanpa harus mengesampingkan faktor ketelitian. Amin Widada, et al. (2006), pada penelitiannya membandingkan pengukuran tinggi dengan metode sipat datar dengan alat GPS. Hasilnya menunjukkan bahwa pengukuran dengan alat GPS jauh lebih ekonomis karena hanya memerlukan waktu kira-kira $\frac{1}{6}$ dibandingkan pengukuran dengan menggunakan metode sipat datar. Fajriyanto (2009) dalam penelitiannya menyatakan bahwa pengukuran koordinat poligon dengan metode konvensional lebih teliti dibandingkan pengukuran dengan GPS Real Kinetik Time (RTK). Sedangkan Ispen Safrel (2010) melakukan pengukuran tinggi titik kerangkan dasar vertikal di Universitas Negeri Semarang dengan menggunakan GPS, hasilnya adalah titik kontrol tinggi mengalami penurunan sekitar $4 \mathrm{~cm}$ dalam kurun waktu satu tahun. Penelitian tersebut menunjukkan bahwa pada saat ini kemampuan alat GPS untuk bidang pengukuran tinggi bisa diandalkan sesuai dengan kebutuhan dan tetap memperhitungkan faktor ketelitian.

Penelitian tentang pengaruh bacaan sudut vertikal dan jarak terhadap tinggi Trigonometrik dilakukan oleh Parseno,et.al (2010) menggunakan Total Station (TS) Nikon DTM 352. Hasilnya adalah sudut vertikal yang bervariasi tidak berpengaruh secara signifikan terhadap jarak maupun beda tinggi hasil ukuran TS. Berdasarkan hasil simulasi, ketelitian beda tinggi dipengaruhi oleh jarak dan sudut elevasi yang digunakan. Akan tetapi untuk jarak sampai dengan $800 \mathrm{~m}$, peningkatannya tidak signifikan. Hasil ukuran lapangan menunjukkan pola hubungan yang acak antara jarak maupun sudut elevasi terhadap ketelitian beda tinggi pada jarak ukuran 50 meter atau lebih, dan kontribusi ketelitian sudut terhadap perubahan ketelitian beda tinggi lebih besar dibandingkan kontribusi ketelitian jarak. Arintia et.al.(2014) melakukan pengukuran posisi titiktitik dengan metode ekstraterestrial menggunakan receiver GPS dengan menggunakan pengukuran dan pengolahan data yang diperoleh dari hasil pengukuran TS sebagai acuan. Hasilnya ketelitian pengukuran luasan dan koordinat bidang tanah yang diperoleh dari hasil pengukuran dengan menggunakan receiver Trimble GeoXT 3000 series metode penentuan posisi diferensial dengan sistem DGPS (Differential Global Positioning System) metode post processing untuk pemetaan bidang-bidang tanah lebih tinggi dibandingkan dengan metode pengolahan secara absolut.

Penelitian Githa (2015) bertujuan untuk mengetahui pengaruh penerapan model koreksi beda tinggi metode Trigonometri yaitu $\mathrm{y}=0,000126 \mathrm{x}+0,0014$ terhadap ketelitian penentuan tinggi yang dihasilkan, dengan mengambil kasus jaring pemantau stabilitas Candi Borobudur. Data yang digunakan adalah jaring vertikal Sipat Datar Leica SPRINTER-100 Candi Borobudur tahun 2011 dan data jaring vertikal TS Nikon DTM-322 Candi Borobudur tahun 2012. Pada jaring vertikal TS diberikan model koreksi y $=0,000126 x+0,0014$, dan data diproses dengan hitung perataan kuadrat terkecil dengan metode parameter terkendala minimal. Pengujian analisis hasil dilakukan dengan Uji Fisher dan Uji-t dengan tingkat kepercayaan 95\%. Pengujian dilakukan pada varian masing-masing data yang dihasilkan, kemudian dilakukan pengujian tinggi titik yang diestimasi untuk melihat hasil penentuan tinggi dengan TS yang dibandingkan dengan Sipat Datar. Hasil penerapan model koreksi beda tinggi pada jaring vertikal TS Nikon DTM-322 bersifat sistematis, dan ternyata model koreksi tersebut tidak secara signifikan memberikan perubahan pada ketelitian pengukuran yang dilakukan. Gondang et al (2017) melakukan analisis ketelitian penentuan beda tinggi secara Reciprocal Trigonometric Levelling (TL) dengan TS akurasi 1" (TS 1") pada jaringan titik kontrol rute pendek. Hasilnya adalah nilai koordinat tinggi dan simpangan baku hasil pengukuran TL dengan TS 1" dan pada geometric levelling (GL) 
dengan Waterpass Digital pada penelitian ini tidak berbeda signifikan secara statistik. Pengukuran TL dengan TS 1" pada rute pendek termasuk di kelas LA (kelas kedua) pada Standar Nasional Indonesia (SNI) Jaring Kontrol Vertikal JKV). Dalam kasus pemetaan topografi skala besar dan pekerjaan rekayasa lain metode TS dengan TS 1" dapat dikatakan memiliki ketelitian yang cukup baik. Kajian ketelitian tentang pengukuran JKV dilakukan oleh Anindya et al. (2018) menggunakan TS dengan akurasi sudut 1" dan 5" dibandingkan dengan nilai yang dianggap benar dengan Digital Level. Metode yang dipakai adalah Trigonometrik Teknik Resiprokal dengan pengukuran 15 pilar titik kontrol berbentuk loop. Data diolah dengan metode Bowditch dan Hitung Kwadrat Terkecil metode parameter, Hasilnya adalah semakin rendah akurasi sudut TS maka semakin berkurang ketelitiannya dalam pengukuran JKV. Khomsin et al (2018) melakukan penelitian dengan mengukur 2 stockpile dan membandingkan hasil perhitungan volume dari data TS, TLS (Terrestrial Laser Scanner), dan GPS. Data pengukuran TLS dipakai sebagai acuan, uji ketelitian menggunakan RMSE (Root Mean Square Error) dilakukan di beberapa titik ICP (Independent Check Point). Diperoleh nilai RMSE volume antara TS dan TLS memiliki selisih kecil. Sedangkan hasil perhitungan volume dengan GPS RTK dan TLS memiliki nilai deviasi yang lebih besar pada area studi. Hasil uji RMSE dari Independent Check Point (ICP) didapatkan RMSE dari hasil koordinat TS terhadap TLS pada area studi yang berada di gudang sebesar $0,001 \mathrm{~m}$ pada absis, $0,002 \mathrm{~m}$ pada ordinat, dan $0,001 \mathrm{~m}$ pada ketinggian. Pada GPS RTK $(0,007) \mathrm{m}$ pada absis, $(0,006) \mathrm{m}$ pada ordinat, dan $(0,005) \mathrm{m}$ pada ketinggiannya. Pada studi area timbunan didapatkan nilai RMSE pada Total Station $(0,002) \mathrm{m},(0,001) \mathrm{m},(0,002) \mathrm{m}$ dan pada GPS RTK $(0,008) \mathrm{m},(0,008) \mathrm{m},(0,004) \mathrm{m}$.

Pada penelitian ini dilakukan pengukuran tinggi dengan menggunakan alat TS Kolida type 420SR yang dibandingkan dengan sipat datar jenis Topcon B2. Pemilihan metode ini dilakukan dengan didasari oleh keterbatasan kesempatan dan biaya, sehingga luasan pada daerah penelitian ini hanya sekitar $2200 \mathrm{~m}^{2}$. Tujuan penelitian ini adalah untuk mengetahui tingkat ketelitian pengukuran beda tinggi yang dilakukan dengan alat TS serta efisiensi waktu pelaksanaan pekerjaan jika pekerjaan yang sama dilakukan dengan alat sipat datar. Manfaat penelitian yang dilakukan adalah untuk memberi masukan kepada pelaksana teknis di lapangan dalam melaksanakan pekerjaannya tentang seberapa jauh ketelitian TS dapat digunakan untuk pengukuran beda tinggi, serta waktu yang diperlukan jika pekerjaan tersebut dilaksanakan dengan alat sipat datar, sehingga diharapkan dapat memberikan kontribusi kepada para pelaksana di lapangan dalam pemilihan metode maupun peralatan yang digunakan.

Untuk meminimalkan pengukuran yang mengandung suatu kesalahan yang sifatnya acak, maka dilakukan hitung perataan atau lebih dikenal dengan statistik geodetik yang merupakan ilmu yang mempelajari tentang perhitungan statistik. Dengan hitung perataan, maka nilai koreksi yang didapat diberikan kepada hasil pengukuran, sehingga hasil pengukuran memenuhi syarat geometriknya (Wolf, 1980). Syarat geometrik merupakan suatu kondisi yang harus dipenuhi dari hubungan suatu pengukuran dengan pengukuran lainnya.

\section{METODE PENELITIAN}

Untuk mendapatkan ketelitian beda tinggi yang baik dalam pekerjaan Teknik Sipil, Waterpassing adalah jawabannya. Namun Waterpass mempunyai jangkauan teropong vertikal yang terbatas, maka pengukuran beda tinggi dengan alat ini mempunyai kesulitan tersendiri dan memerlukan waktu yang lama terutama untuk medan permukaan bumi yang berbukit. Apabila persyaratan ketelitian tidak dituntut sangat tinggi, maka diperlukan alat yang mampu menjawab persoalan tersebut, yaitu pekerjaan dilakukan secara cepat tentu saja persyaratan ketelitian juga harus 
dipenuhi. Pada penelitian ini penulis mencoba untuk menjawab permasalahan tersebut. Tahapan penelitian secara garis besar adalah:

A. Pengukuran Lapangan

Pada penelitian ini dibuat suatu jaring sipat datar sederhana tertutup yang diukur dengan waterpass dan TS. Penelitian dilaksanakan di Ciloto, Puncak Jawa Barat dengan koordinat $107^{\circ}$ bujur timur dan $06^{\circ}$ lintang selatan, pada tanggal 14 dan 15 Desember 2014 dengan menggunakan titik tinggi lokal, dengan bentuk jaring sipat datar adalah:
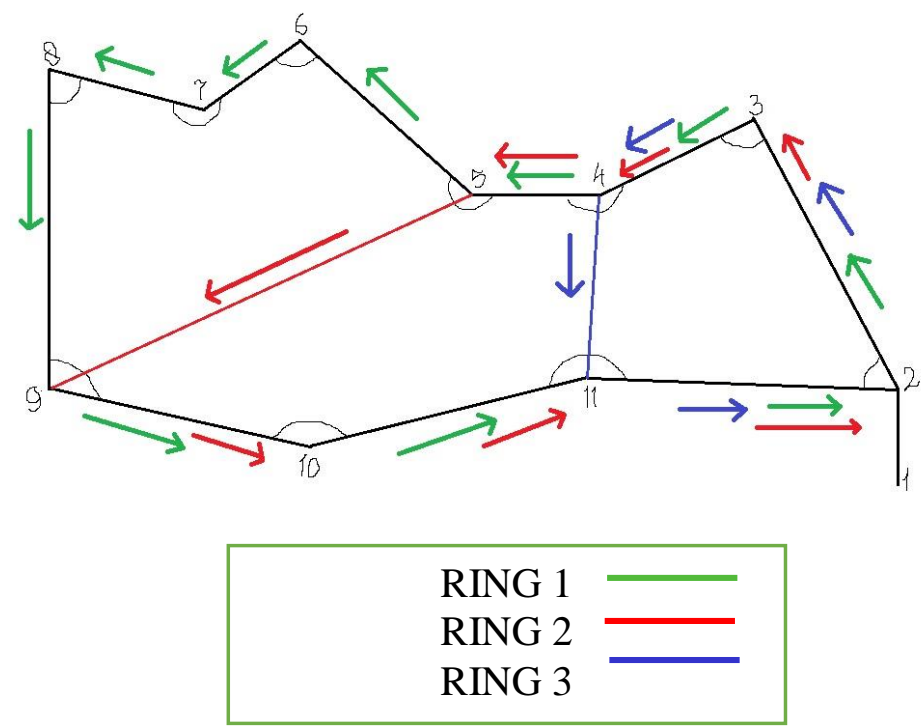

Gambar 2. 1 Sketsa Pengukuran

Pengukuran dibagi menjadi tiga ring atau sirkuit,yaitu:

1. Ring 1 dimulai dari titik 2,3,4,5,6,7,8,9,10,11,2

2. Ring 2 dimulai dari titik $2,3,4,5,9,10,11,2$

3. Ring 3 dimulai dari titik 2,3,4,11,2

B. Pengolahan Data dan Analisis

Data hasil dari lapangan dihitung untuk mengetahui tinggi titik-titik yang diukur, referensi tinggi adalah koordinat local. Kemudian tinggi titik-titik hasil perhitungan dengan menggunakan kedua alat dihitung standar deviasinya dengan hitung perataan atau statistik Geodesi supaya diketahui ketelitian pengukuran beda tingginya. Analisis ketelitian dilakukan berdasarkan nilai standar deviasi hasil pengukuran dengan kedua alat.

Proses hitung perataan dengan menggunakan metode kuadrat terkecil sebagai berikut: (Wolf,1980 halaman 167)

$$
\begin{aligned}
& \mathrm{B}(\mathrm{L}+\mathrm{V})=\mathrm{C} \\
& \mathrm{BL}+\mathrm{BV}=\mathrm{C} \\
& \mathrm{BV}=\mathrm{C}-\mathrm{BL}
\end{aligned}
$$

Standard deviasi:

$$
\text { So }=\sqrt{\frac{\sum p v^{2}}{n-1}}
$$


Perataan jaring sipat datar pada penelitian ini terdapat 12 jalur pengukuran, dan ada 9 titik yang tidak diketahui tingginya, sehingga ada $12-9=3$ persamaan kondisi. Adapun persamaan kondisi yang dibuat adalah:

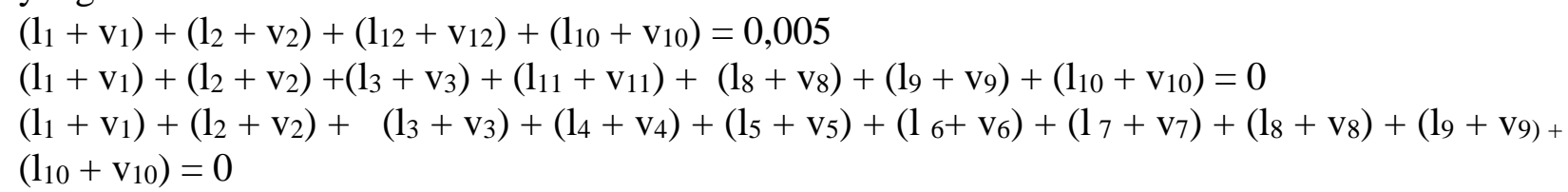

\section{HASIL DAN PEMBAHASAN}

\section{1 Perataan Data Sipat Datar}

Matriks B dapat dinyatakan dibawah ini

$$
\mathrm{B}=\left|\begin{array}{llllllllllll}
1 & 1 & 1 & 1 & 1 & 1 & 1 & 1 & 1 & 1 & 0 & 0 \\
1 & 1 & 1 & 0 & 0 & 0 & 0 & 1 & 1 & 1 & 1 & 0 \\
1 & 1 & 0 & 0 & 0 & 0 & 0 & 0 & 0 & 1 & 0 & 1
\end{array}\right|
$$

Untuk matriks C adalah:

$$
\mathrm{C}=\left|\begin{array}{l}
0,009 \\
0,006 \\
0,005
\end{array}\right|
$$

Sedangkan untuk matriks L adalah:

$$
\mathrm{L}=\left|\begin{array}{c}
-0.846 \\
-0.533 \\
-0.661 \\
-0.823 \\
-0.051 \\
-0.062 \\
-0.013 \\
1.042 \\
0.966 \\
0.99 \\
-0.954 \\
0.434
\end{array}\right|
$$

Sedangkan B X B ${ }^{\mathrm{T}}$ adalah:

$$
\mathrm{W}=\left|\begin{array}{c}
0 \\
0.02 \\
0.05
\end{array}\right|
$$

$\begin{array}{lll}10 & 6 & 3 \\ 6 & 7 & 3 \\ 3 & 3 & 4\end{array}$

Invers dari matriks $\mathrm{B} \mathrm{X} \mathrm{B}^{\mathrm{T}}$ adalah:

$\mathrm{B}^{\mathrm{T}} \times\left(\mathrm{BB}^{\mathrm{T}}\right)^{-1}$ adalah:

$\left|\begin{array}{rrr}0,208791 & -0,16484 & -0,03296703 \\ -0,16484 & 0,340659 & -0,13186813 \\ -0,03297 & -0,13187 & 0,37362637\end{array}\right|$

$\left|\begin{array}{lll}0,010981 & 0,043949 & 0,208791 \\ 0,010981 & 0,043949 & 0,208791 \\ 0,043951 & 0,175819 & -0,16484 \\ 0,208791 & -0,16484 & -0,03297\end{array}\right|$




$\left|\begin{array}{lll}0,208791 & -0,16484 & -0,03297 \\ 0,208791 & -0,16484 & -0,03297 \\ 0,208791 & -0,16484 & -0,03297 \\ 0,043951 & 0,175819 & -0,16484 \\ 0,043951 & 0,175819 & -0,16484 \\ 0,010981 & 0,043949 & 0,208791 \\ -0,16484 & 0,340659 & -0,13187 \\ -0,03297 & -0,13187 & 0,373626\end{array}\right|$

$\mathrm{V}=\mathrm{B}^{\mathrm{T}} \mathrm{x}\left(\mathrm{BB}^{\mathrm{T}}\right)^{-1} \mathrm{x} \mathrm{W}$

$$
\mathrm{V}=\left|\begin{array}{r}
0.011319 \\
0.011319 \\
-0.00473 \\
-0.00495 \\
-0.00495 \\
-0.00495 \\
-0.00495 \\
-0.00473 \\
-0.00473 \\
0.011319 \\
0.00022 \\
0.016044
\end{array}\right|
$$

Setelah dihitung dengan rumus [2.6], maka standar deviasi pengukuran dengan Waterpass adalah $0,009822881 \mathrm{~mm}$ atau $0,01 \mathrm{~mm}$.

\subsection{Hitungan Perataan Data Total Station}

Berikut ini hitungan perataan tinggi yang diperoleh dengan Total Station:

Matriks B dapat dinyatakan dibawah ini

$$
\mathrm{B}=\left|\begin{array}{llllllllllll}
1 & 1 & 1 & 1 & 1 & 1 & 1 & 1 & 1 & 1 & 0 & 0 \\
1 & 1 & 1 & 0 & 0 & 0 & 0 & 1 & 1 & 1 & 1 & 0 \\
1 & 1 & 0 & 0 & 0 & 0 & 0 & 0 & 0 & 1 & 0 & 1
\end{array}\right|
$$

Untuk matriks $\mathrm{C}$ adalah:

$$
\mathrm{C}=\left|\begin{array}{c}
-0.014 \\
-0.031 \\
0.014
\end{array}\right|
$$

Untuk matriks L adalah:

$$
\left|\begin{array}{c}
-0.84 \\
-0.54 \\
-0.638 \\
-0.798
\end{array}\right|
$$


Jurnal Muara Sains, Teknologi, Kedokteran, dan Ilmu Kesehatan Vol. 5, No. 2, Oktober 2021: hlm 259-268

$$
\mathrm{L}=\left|\begin{array}{c}
-0.049 \\
-0.076 \\
-0.012 \\
1.053 \\
0.941 \\
0.953 \\
-0.89 \\
0.404
\end{array}\right|
$$

Sedangkan B X B ${ }^{\mathrm{T}}$ adalah:

$$
\left|\begin{array}{ccc}
10 & 6 & 3 \\
6 & 7 & 3 \\
3 & 3 & 4
\end{array}\right|
$$

$\mathrm{B}^{\mathrm{T}} \times\left(\mathrm{BB}^{\mathrm{T}}\right)^{-1}$ adalah:

$\begin{array}{|lll|}0,010981 & 0,043949 & 0,208791 \\ 0,010981 & 0,043949 & 0,208791 \\ 0,043951 & 0,175819 & -0,16484 \\ 0,208791 & -0,16484 & -0,03297 \\ 0,208791 & -0,16484 & -0,03297 \\ 0,208791 & -0,16484 & -0,03297 \\ 0,208791 & -0,16484 & -0,03297 \\ 0,043951 & 0,175819 & -0,16484 \\ 0,043951 & 0,175819 & -0,16484 \\ 0,010981 & 0,043949 & 0,208791 \\ -0,16484 & 0,340659 & -0,13187 \\ -0,03297 & -0,13187 & 0,373626\end{array}$

$$
\mathrm{V}=\mathrm{B}^{\mathrm{T}} \mathrm{x}\left(\mathrm{BB}^{\mathrm{T}}\right)^{-1} \mathrm{x} \mathrm{W}
$$

$$
V=\left|\begin{array}{r}
0.007286 \\
0.007286 \\
-0.00786 \\
-0.00157 \\
-0.00157 \\
-0.00157 \\
-0.00157 \\
-0.00786 \\
-0.00786 \\
0.007286 \\
-0.00629 \\
0.015143
\end{array}\right|
$$

ISSN 2579-6402 (Versi Cetak) ISSN-L 2579-6410 (Versi Elektronik)

$$
\mathrm{W}=\left|\begin{array}{c}
-0.008 \\
-0.008 \\
0.037
\end{array}\right|
$$

Invers dari matriks $\mathrm{B} \times \mathrm{B}^{\mathrm{T}}$ adalah:

$\begin{array}{|rrr|}0,208791 & -0,16484 & -0,03296703 \\ -0,16484 & 0,340659 & -0,13186813 \\ -0,03297 & -0,13187 & 0,37362637\end{array} \mid$


Setelah dihitung dengan rumus [2.6], maka standar deviasi pengukuran dengan TS adalah $0,018139 \mathrm{~mm}$ atau $0,02 \mathrm{~mm}$. Hasil kesalahan pengukuran tinggi dengan alat waterpass maupun TS disajikan pada tabel 3.1.

Tabel 3. 1 Hasil pengukuran kesalahan penutup tinggi dengan alat Waterpass dan Total Station

\begin{tabular}{cccc}
\hline No & Ring & Alat & Kesalahan penutup tinggi $(\mathbf{m m})$ \\
\hline $\mathbf{1}$ & 1 & Waterpass & 9 \\
\hline $\mathbf{2}$ & 1 & Theodolit Total Station & 14 \\
\hline $\mathbf{3}$ & 2 & Waterpass & 4 \\
\hline $\mathbf{4}$ & 2 & Theodolit Total Station & 31 \\
\hline $\mathbf{5}$ & 3 & Waterpass & 5 \\
\hline $\mathbf{6}$ & 3 & Theodolit Total Station & 14 \\
\hline
\end{tabular}

Berdasarkan hasil perhitungan yang disajikan pada tabel 3.1 terlihat bahwa pengukuran beda tinggi dengan alat Waterpass mempunyai kesalahan penutup tinggi yang lebih kecil dibandingkan dengan kesalahan penutup tinggi dengan alat TS. Pengukuran beda tinggi dengan TS menggunakan prinsip Trigonometri dengan pengukuran sudut vertikal, jarak horizontal yang secara terintegrasi sudah dihitung dalam prosesor TS dan dihitung sebagai beda tinggi seperti pada prinsip Takhimetri. Tidak seperti alat Waterpass dengan kedudukan teropong yang hanya dapat digerakkan pada arah horizontal, tidak dapat digerakkan pada arah vertikal, sehingga tidak ada kesalahan pembacaan sudut vertikal yang mempengaruhi, maka kesalahan dalam pengukuran tinggi dengan Waterpass relative lebih kecil dibandingkan dengan pengukuran tinggi dengan TS.

Karena hasil pengukuran beda tinggi pada TS didasarkan pada pengukuran sudut elevasi, maka pengamatan sudut elevasi pada TS mempunyai pengaruh terhadap hasil ukuran tinggi. Berdasarkan penelitian yang sudah dilakukan terdahulu, ketelitian beda tinggi dengan metode Trigonometrik tidak hanya dipengaruhi oleh sudut elevasi, akan tetapi jarak juga mempunyai kontribusi terhadap ketelitian beda tinggi. Walaupun sudut elevasi dan jarak pada pengukuran beda tinggi dengan TS mempengaruhi ketelitian, akan tetapi dalam penelitian ini dihasilkan selisih standar deviasi untuk pengukuran dengan Waterpass dan TS sebesar 0,01 mm.

Pengukuran dan pengolahan data yang diperoleh dari hasil pengukuran TS pernah digunakan sebagai acuan terhadap beda tinggi yang diukur dengan alat lain. Pada penelitian lain hasil penerapan model koreksi beda tinggi pada jaring vertikal TS bersifat sistematis, dan ternyata model koreksi tersebut tidak secara signifikan memberikan perubahan pada ketelitian pengukuran yang dilakukan. Hasil nilai koordinat tinggi dan simpangan baku hasil pengukuran TL dengan TS 1" dan pada Geometric Levelling dengan Waterpass Digital pada penelitian lain tidak berbeda signifikan secara statistik. Pengukuran TL dengan TS 1" pada rute pendek termasuk di kelas LA (kelas kedua) pada SNI JKV. Dalam kasus pemetaan topografi skala besar dan pekerjaan rekayasa lain metode TL dengan TS 1" dapat dikatakan memiliki ketelitian yang cukup baik. Semakin rendah akurasi sudut TS maka semakin berkurang ketelitiannya dalam pengukuran JKV. Untuk keperluan pekerjaan Teknik Sipil selisih tersebut tidak terlalu signifikan, sehingga pengukuran beda tinggi dengan TS untuk pekerjaan yang tidak memerlukan ketelitian sangat tinggi dapat digunakan. Secara garis besar tingkat ketelitian pengukuran tinggi dengan alat TS dapat digunakan mengingat bahwa ketelitian yang dihasilkan tidak terlalu jauh dari alat Waterpass. 
Dalam segi pelaksanaan waktu pengukuran, untuk daerah seluas $2200 \mathrm{~m}^{2}$ pengukuran dengan TS hanya memerlukan waktu sekitar 4 jam, sedangkan pengukuran dengan Waterpass memerlukan waktu sekitar 16 jam. Jadi pengukuran dengan TS lebih efisien dari segi waktu dan tentu saja menyangkut masalah biaya yang akan di pergunakan dalam pekerjaan Teknik sipil dilapangan. Pada prinsipnya pengukuran tinggi untuk daerah yang luas yang dituntut ketelitian tinggi dapat dilakukan dengan kombinasi alat Waterpass dan TS. Pada pengukuran awal, alat TS digunakan, apabila perataan daerah sudah dilakukan sesuai dengan tinggi yang dikehendaki, untuk mendapatkan ketelitian tinggi yang dikehendaki digunakan Waterpass.

\section{KESIMPULAN DAN SARAN}

Setelah melalui pengukuran dan perhitungan beda tinggi dengan studi kasus daerah Ciloto, Puncak Jawa Barat, serta hasil para peneliti terdahulu maka:

\section{Kesimpulan}

a. Berdasarkan hasil pengukuran yang telah dilakukan, Standar deviasi pengukuran beda tinggi dengan Waterpass sebesar 0,01 mm, dengan Total Station $0.02 \mathrm{~mm}$. Kesalahan penutup tinggi dengan Waterpass yaitu $9 \mathrm{~mm}, 4 \mathrm{~mm}$ dan $5 \mathrm{~mm}$ pada ring 1, ring 2, dan ring 3. Sedangkan kesalahan penutup tinggi pada Total Station $14 \mathrm{~mm}, 31 \mathrm{~mm}, 14 \mathrm{~mm}$ masing-masing pada ring 1 , ring 2 , dan ring 3 .

b. Waktu yang diperlukan untuk pengukuran dengan menggunakan alat Total Station hanya 1/4 waktu pengukuran yang menggunakan alat Waterpass.

c. Penggunaan Total Station sangat efisien digunakan untuk pengukuran wilayah yang luas.

d. Berdasarkan hasil dari peneliti terdahulu, Total Station dapat dipakai sebagai acuan tinggi untuk pengukuran beda tinggi dengan alat lain, menentukan posisi koordinat titik-titik di permukaan bumi, pengukuran untuk luas dan volume, dengan menghasilkan ketelitian yang cukup baik.

e. Semakin rendah akurasi sudut Total Station, maka semakin rendah ketelitian pengukurannya.

\section{Saran}

Berdasarkan hasil penelitian, maka disarankan hal-hal sebagai berikut:

a. Penelitan ini perlu dikembangkan lagi untuk pengukuran pada daerah yang lebih luas dan kontur tanah yang yang lebih berbukit, dan datar agar semakin kelihatan ketelitian dari kedua alat yang digunakan.

b. Pengukuran dengan luasan yang lebih dari $2200 \mathrm{~m}^{2}$, jumlah ring diperbanyak, untuk melihat ketelitian dan kesalahan yang terjadi saat pengukuran agar diperoleh data yang lebih akurat.

\section{REFERENSI}

Basuki, Slamet (2011), Ilmu Ukur Tanah, Edisi Revisi, Gadjah Mada University Press, Yogyakarta.

Charles D. Ghilani and Paul R Wolf, (2006), Adjustment Computations Spatial Data Analysis, E-Book, Fourth Edition, John and Wiley Sons Inc.

Eka Ningsih, A. R. I. N. T. I. A., Awaluddin, M., Darmo Yuwono, B., \& Putra Wijaya, A. (2014). Kajian Pengukuran Dan Pemetaan Bidang Tanah Metode DGPS Post Processing Dengan Menggunakan Receiver Trimble GeoXT 3000 Series (Doctoral

Fajriyanto, F. (2009). Studi Komparasi Pemakaian Gps Metode Real Time Kinematic (Rtk) Dengan Total Station (Ts) Untuk Penentuan Posisi Horisontal. Jurnal Rekayasa Teknik Sipil Universitas Lampung, 13(2), 140254. 
Githa Eka Rosalina, (2015), Studi Penerapan Model Koreksi Beda Tinggi Metode Trigonometri Pada Titik-Titik Jaring Pemantau Vertikal Candi Borobudur Dengan Total Station, Jurnal Ilmiah Geomatika Volume 21 Nomor 2 Desember 2015: 91 - 98

Prasidya, A. S., \& Riyadi, G. (2018). Kajian Ketelitian Pengukuran Kerangka Kontrol Vertikal Menggunakan Total Station Akurasi Sudut 1" Dan 5". Elipsoida: Jurnal Geodesi dan Geomatika, 1(02), 71-78.

Riyadi, G., \& Prasidya, A. S. (2017). Analisis Ketelitian Penentuan Beda Tinggi secara Trigonometrik Teknik Resiprokal dengan Total Station Akurasi 1" Pada Jaringan Titik Kontrol Rute Pendek. In Prosiding Seminar Nasional Teknologi Terapan (SNTT) SV $U G M$.

Khomsin, K., Pratomo, D. G., \& Akbar, A. F. (2018). Analisa Perbandingan Volume 3'S (TS, GNSS, \&TLS). Geoid, 14(1), 113-123.

Parseno dan Yulaikhah, (2010), Pengaruh Sudut Vertikal Terhadap Hasil Ukuran Jarak Dan Beda Tinggi Metode Trigonometris Menggunakan Total Station Nikon DTM 352, Forum Teknik, Volume 33 Nomor 3 (149-156)

Paul R. Wolf, 1980, Adjustment Computations, $2^{\text {nd }}$ Edition, Edisi Indonesia-Edisi Mahasiswa

Safrel, I. (2010). Evaluasi Titik Kontrol Tinggi Universitas Negeri Semarang Dengan Metode Pengukuran Kerangka Dasar Vertikal Bench Mark (BM). Jurnal Teknik Sipil dan Perencanaan, 12(2).

Widada, A. (2006). Analisa Komparatif Penentuan Tinggi Dengan GPS dan Sipat Datar. Jurnal Ilmiah Geomatika, 12(1), 1-10. 